\title{
Modeling the Effects of Water Temperature on Growth Rates, Gastric Evacuation and the Return of Appetite in Juvenile Nile Tilapia, Oreochromis niloticus L.
}

\author{
Mohamed S. Azaza ${ }^{1} \&$ Mohamed N. Dhraief ${ }^{1}$ \\ ${ }^{1}$ Aquaculture Laboratory, National Institute of Marine Science and Technology, Tunis, Tunisia \\ Correspondence: Mohamed S. Azaza, Aquaculture Laboratory (LR16INSTM03), National Institute of Marine \\ Science and Technology, 28 Rue 2 mars 1934, Carthage Salammbô 2025, Tunis, Tunisia. Tel: 216-98-649-324. \\ E-mail: med.azaza@instm.rnrt.tn
}

Received: May 22, 2020

doi:10.5539/jas.v12n8p191
Accepted: June 24, $2020 \quad$ Online Published: July 15, 2020

URL: https://doi.org/10.5539/jas.v12n8p191

\begin{abstract}
Optimized aquafeeds have long been a major concern of the sustainable aquaculture development. Not only should the feed composition meet the nutritional requirements of the fish, it should also be reasonably managed (feed ration and feeding frequency) to enhance the feed utilisation efficiency, growth performance and decrease the amount of wastes. At present there is no detailed information on how rearing temperature impacts gastric evacuation rate, return of appetite (RA) and daily feed ration among tilapias, considered as one of the leading fish species for worldwide aquaculture production. The objective of this study was to develope mathematical models to estimate maximum daily feed intake for Nile tilapia in relation to feeding frequency and water temperature. Growth was measured in 480 fish (initial body mass $4.30 \pm 0.02 \mathrm{~g}$ ) fed in slight excess, following their exposure to four thermal treatment $\left(22,26,30\right.$ and $34{ }^{\circ} \mathrm{C}$ ) (four replications per treatment, 21-days rearing period, growth monitoring at 5-days intervals). Gastric evacuation and return of appetite measurement were made by radiographic technique.
\end{abstract}

A growth model was developed using a stepwise multiple-regression analysis against fish body mass and water temperature $\left(\mathrm{r}^{2}=0.939, \mathrm{df}=15\right)$ as follow: SGR $(\% \mathrm{M} /$ day $)=-70.606+98.433 \log \mathrm{T}^{\circ}-33.762\left(\log \mathrm{T}^{\circ}\right)^{2}-$ $0.153 \log \mathrm{M}\left(\log \mathrm{T}^{\circ}\right)^{2}$. The gastric emptying was described by an exponential function, which was found to be inversely related to the RA. The instantaneous evacuation rates $(\mathrm{Re})$ determined by linearizing the data were strongly affected by rearing temperature $\left(Q_{10}=0.047\right)$ in Nile tilapia. The RA following a satiation meal was also significantly dependent on rearing temperature. Based on these data, the maximum daily feed consumption was estimated in relation to feeding schedule for juvenile tilapia reared at different temperatures.

Considering that unsuitable use of feed adversely impacts on the farm revenue and profit, these results contribute to improve feed management strategies.

Keywords: gastric evacuation, return of appetite, feeding schedule, water temperature, Nile tilapia

\section{Introduction}

In poikilotherms like fishes, rearing water temperature is one of the most important factors affecting growth performance and other physiological parameters (e.g., digestion, absorption, catabolism, anabolism and excretion). For several of fish species there is detailed information on how temperature affects growth, feed intake, digestibility and feeding behaviour (e.g., Azaza et al., 2008, 2010a; Handeland et al., 2008; El-Asely et al., in press). Generally, he metabolic processes of fish are sensitive to changes in environmental temperature and if water temperatures depart from the optimum, fish eventually lose appetite, reduce feed intake and growth decreases.

For intensive rearing of a fish species to be successful, it is essential that aquafeed be appropriate and sustainable, as feeds represent the main contributor in the production costs, may present from 50 to $60 \%$ of total variable expenses (Azaza et al., 2015). It should improve feed efficiency, promote fish growth and lowest feed wastes. There have been increasing concerns over the sustainability of fish feed, in particular as regards the substitution of costly ingredients. These approaches are prerequisite, but they may not enough, since several other parameters of the practical methods of feed management strategies also affect the feed intake and feeding efficiency of fish 
(Houlihan et al., 2001). In fact, adequate feeding strategy is essential not only in terms of improvement of fish growth but also in terms of reduction of feed cost and environmental impacts.

In fish farming practice, it is important to have information on the rate at which eaten feed is processed in the digestive tract. This is controlled by the storage capacity, rate of digestion, and time taken to the return of appetite (Houlihan et al., 2001). The processes of gastric digestion and evacuation are complex, depending upon the interrelationship of many factors such as temperature, fish mass, meal size, dietary composition, feeding frequency and feed particle size (Bromley, 1994; Pääkkönen \& Marjomaki, 1997; Koed, 2001; Azaza et al., 2010b). Of these factors, water temperature is perhaps the predominant factor affecting the feed conversion efficiency and growth of the fish (Azaza et al., 2008). It has been demonstrated that hunger in fish is, particularly, determined by the amount of feed in stomach tract (i.e., available space in the stomach), at the same time, the return of appetite is strictely related to the rate of gastric emptying (Lee et al., 2000). Determining the gastrointestinal evacuation rate can allow one to predict the return of appetite under a given set of conditions and thus to develop efficient feeding strategies for farming operation to be porofitable. Therefore, estimation of the gastric evacuation rate (GER) is a prerequisite for modeling of daily feed consumption in fish (Azaza et al., 2010b).

little information is available on the GER of $O$. niloticus, these studies have investigated GER in relation to feeding frequency (Riche et al., 2004) and feed particle size (Azaza et al., 2010b). At present, insuffisant information on how rearing temperature affects GER, return of appetite and daily feed ration among tilapias. Consequently, the present study aimed at developing general mathematical models for growth, evacuation and return of appetite in $O$. niloticus based on water temperature, using radiographic tool. Through this study was to demonstrate the useful of this latter technique to elaborate prediction models which are crucial for planning fish production and refining the feeding schedule in intensive culture operations. This which may assist in the development of intensive culture strategies of this species.

\section{Material and Methods}

\subsection{Fish and Experimental Rearing Conditions}

O. niloticus fingerlings of Maryut strain of both sexes, weighing $4.30 \pm 0.02 \mathrm{~g} \mathrm{fish}^{-1}(n=480$, mean $\pm \mathrm{SE})$, were selected from a large population maintained at $28-30{ }^{\circ} \mathrm{C}$ at the fish-culture research station of the Tunisian National Institute of Marine Sciences and Technologies (INSTM). Fish were sedated with tricaine methanesulphonate $\left(50 \mathrm{mg} \mathrm{L}^{-1}\right)$, weighed individually to produce 16 groups of 30 fish each, in which mean mass and size heterogeneity (expressed by coefficient of variation of fish mass, $\mathrm{CV}<8 \%$ ) were as similar as possible. Thereafter, the groups of fish were randomly allocated to the different thermal treatments $\left(22,26,30\right.$ and $\left.34{ }^{\circ} \mathrm{C}\right)$ and tested in quadruplicate for 3 weeks. According to Azaza et al. (2008) this period allowed reliable recordings of growth of juvenile $O$. niloticus reared at $22{ }^{\circ} \mathrm{C}$.

The four thermal regimes were evaluated in four indoor water recirculating systems in the rearing facilities of the Aquaculture Research Station, previously described in Azaza et al. (2008, 2010b). Each system comprised four $85 \mathrm{~L}$ rearing aquaria $(35 \times 80 \times 45) \mathrm{cm}^{3}$, a 180 -L reservoir tank for filtration. In order to maintain the temperature of the water, a $2-\mathrm{kW}$ thermostatic immersion heater was used. A 20-L biofilter with UV-sterilization lamp (Oase, model Filtoclear UWC 9/11W; www.pondsupplies.com.au) was also used for water treatment.

Faecal matter removal was accomplished by siphoning out the sedimented feacal matter and uneaten feed (if any). Also, a submerged filtration (Rena, Filstar) was installed in each aquarium to improve filtration process. A light/dark cycle of 12:12 h (08:00-20:00, light period) was maintained, by an automatic timer (Time switch, CHNT), throughout the experiment with four fluorescent lamps suspended over the aquaria and provided about 800 lux (Digital Lux Meter, Digital Instrument LX-101) light intensity at the surface of the water. Before the start of the experiment, fish were kept for one week to acclimatize them to the rearing environment. During this period water temperature was maintained circa $28^{\circ} \mathrm{C}$ in all aquaria, and all dead or apparently stressed fish were substituted. Following acclimation, a 21-day thermal treatment trial was conducted. Experimental target water temperatures were attained progressively by heating or cooling water at $1{ }^{\circ} \mathrm{C} \mathrm{h}^{-1}$. The experiment was conducted during winter, when the air temperature inside the rearing facility was cool enough to enable to maintain easily the lowest experimental temperature (i.e., $22{ }^{\circ} \mathrm{C}$ ). In all aquaria, water flow was adjusted to $1.5-2.5 \mathrm{~L} \mathrm{~min}^{-1}$ to provide oxygen and remove excess nitrogenous wastes. Air stones were placed within each aquarium, to maintain adequate dissolved oxygen levels, if necessary.

The temperature of each aquarium was recorded using temperature loggers (Tidbit ${ }^{\circledR}$ v2 Temp Logger, Onset, USA). For water quality monitoring, dissolved oxygen and $\mathrm{pH}$ levels were recorded automatically (every hour) with a digital thermo-oxymeter surveillance system (WTW, MIQ/C184, www.memecosales.com; accuracy of 
$0.1{ }^{\circ} \mathrm{C}$ and $0.1 \mathrm{mg} \mathrm{O}_{2} \mathrm{~L}^{-1}$ ). Total ammonium and nitrite were measured on the days of fish measurement (days 6, 11, 16 and 21) by standard methods (APHA, 1995).

Fish were fed with formulated feed $\left(350 \mathrm{~g} / \mathrm{kg}\right.$ crude protein, $99 \mathrm{~g} / \mathrm{kg}$ fat and $17.40 \mathrm{~kJ} \mathrm{~g}^{-1}$ gross energy) which stimulate good growth performance (Azaza et al., 2015). The feed was prepared as described by Azaza et al. (2009). Fish were hand-fed to apparent satiety four times daily during the week (0800, 1100, 1400 and $1700 \mathrm{~h})$. Pellets were distributed slowly, allowing all fish to eat without feed wastage. Apparent satiation was considered achieved when the fish would no longer accept the offered feed after a period of active feeding. On days 6, 11, 16 and 21, all fish in each aquarium were individually weighed. Fish were captured with a dipnet, sedated with MS-222, $100 \mathrm{ppm}$, (tricaine methanesulfonate) in order to reduce stress and to improve the accuracy of the weighing, and then weighted individually to the nearest $0.01 \mathrm{~g}$ and returned to their aquarium. On the weighing days, feeding fish was suspended during the morning, and resumed in the early afternoon, in order to enable all fish to recover from handling stress.

\subsection{Gastric Evacuation and the Return of Appetite}

For the gastric evacuation measurement, the feed was similar except that X-ray-dense lead glass beads (Ballotini, type $\mathrm{H}, 450-600 \mu \mathrm{m}$ diam, DLO, Braine-L'Alleud, Belgium) were mixed $\left(1.5 \%, \mathrm{M} \mathrm{M}^{-1}\right)$ with the ingredients before compressing them into pellets using a meat grinder. Marked feed was prepared as described in Azaza et al. (2010b, 2013). Finally, the moist pellets were sun-dried and conserved in sealed containers at $-20{ }^{\circ} \mathrm{C}$ until use. Thirty-five samples of marked feed of known masses (0.05-1.5 g) were X-rayed to determine the relationship between the masses of particles feed and the number of Ballotini $(\mathrm{Nb})$; (feed mass $(\mathrm{g})=0.0073 \mathrm{Nb}+0.0037$; with $\mathrm{r}^{2}=0.974 ; n=35$. This enabled the amount of feed in the gastro-intestinal tracts of fish to be back-calculated from X-ray plates.

The stomach evacuation experiments began at the end of the growth trials because its protocol was potentially more stressing for the fish and required a 2-day period of feed deprivation, which would have impacted on fish growth. Fish were deprived of feed for $48 \mathrm{~h}$ to ensure complete gut emptying. On day 23, the fish in all aquaria were fed to satiation with Ballotini marked feed. Labeled feed was presented to the fish in the same manner as the standard diet. Just after the last pellets were delivered (time zero), and every 2 hours thereafter, six fish were randomly sampled in each aquarium, anesthetized with tricaine methanesulfonate (100 ppm), X-rayed (see below), weighed (nearest $0.01 \mathrm{~g}$ ), then tagged to avoid the fish being sampled again, before at least 6 hours. The decrease in the amount of marked feed in the gastrointestinal tract over time was used to estimate the gastric evacuation rate (GER). After a deprivation period of $36 \mathrm{~h}$ to ascertain that evacuation was complete in all groups, a satiation meal with unlabeled feed was offered to all aquaria. Then the return of appetite was measured every 2 hours (0-18 h) after the satiation meal, by offering a labeled diet (same as for the gut emptying experiment) until apparent satiation. Six fish from each aquarium were randomly sampled for X-ray photographs (same protocol as above). The increases of the amount of ingested marked feed with increasing deprivation time were served to estimate the return of appetite (RA).

\subsection{X-Ray Protocol}

The radiographs were determined using the X-ray protocol described in Azaza et al. (2010b) and Azaza et al. (2013). The radiographs were taken using GE AMX 110 X-ray machine and Kodak Ma film (Kodack, X-OMAT MA), the exposure time was $2 \mathrm{~s}$ at $2 \mathrm{kv}$. An example of a typical radiograph is given in figure 1 to show the number of Ballotini. Stomach content was estimated by counting the radio-opaque Ballotini which easily identified on X-ray photographs. Following the development of X-ray plates, two independent observers counted the number of radio-opaque beads in the gastrointestinal tract of each fish. Counting of glass bead is facilitated by viewing developed plates on a light box. The gastrointestinal tract contents were calculated in terms of percent body mass following the relationship between feed mass and the number of glass beads. 


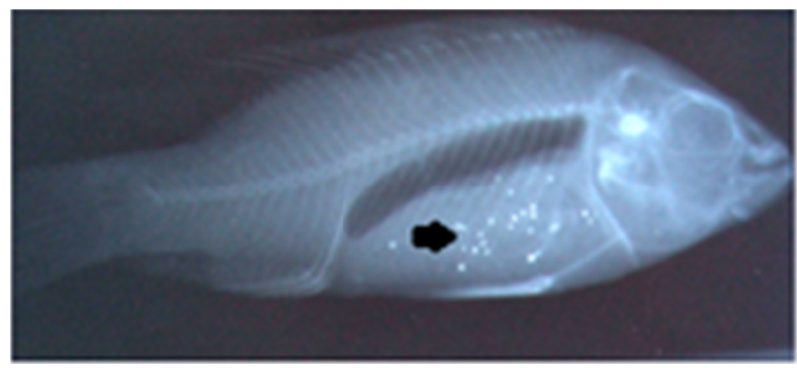

Figure 1. Radiograph showing feed intake of diet estimated by the number of radio-opaque glass beads (arrows) in the gut

\subsection{Calculation, Modeling Data and Statistics}

Growth performance was expressed as the specific growth rate (SGR, $\left.\% \mathrm{M} \mathrm{day}^{-1}\right)$, which was calculated as:

$$
S G R=100 \times \operatorname{Ln}\left(M_{2} \cdot M_{1}^{-1}\right) \cdot\left(t_{2}-t_{1}\right)^{-1}
$$

where, $\mathrm{M}_{2}$ and $\mathrm{M}_{1}$ are the mean body masses at times $\mathrm{t}_{2}$ and $\mathrm{t}_{1}$, respectively.

Data points before emptying had started or after the evacuation had almost ceased were excluded from the evacuation rate calculation to avoid bias (Temming \& Andersen, 1994; Azaza et al., 2010b). A Logit transformation was used to stabilize the variances of the instantaneous gastric evacuation rate where the variance increases with the mean. A stepwise multiple-regression analysis was used to test for the effect of the thermal treatment on the growth of fish, using the 64 data points (i.e., 4 measurements of fish; on days $6,11,16$ and $21 \times$ 4 experimental temperatures $\times 4$ replicates per experimental temperature). The explicative variables were fish mass $(\mathrm{M}, \mathrm{g})$, the rearing temperature $\left(\mathrm{T},{ }^{\circ} \mathrm{C}\right)$, and the interaction of the variables. All variables were tested in linear and $\log 10$ form. Null hypotheses were rejected at $P<0.05$.

The development of the growth model across fish mass and rearing temperature was based on the relationships between SGR and water temperature $\left(\mathrm{T}^{\circ}\right)$ for fish of increasing mass $(\mathrm{M})$. These mathematical functions were a series of polynomials of decreasing magnitude (along SGR) and amplitude (along $\mathrm{T}^{\circ}$ ). Given that the relationship between SGR and fish masses $M$ at a specific temperature fitting a power function, the decrease in the magnitude of the polynomial models plotting SGR across $\mathrm{T}^{\circ}$ was pretended to follow a fit of similar trend, thus achieving the following conceptual model (Baras et al., 2000):

$$
\log (n+S G R)=a+b \cdot T^{\circ} \cdot\left[\operatorname{or} \log \left(T^{\circ}\right)\right]+c \cdot T^{\circ} \cdot m \cdot\left[\operatorname{or} \log \left(T^{\circ} \cdot m\right)\right]+d \cdot \log (M)
$$

where, SGR is the specific growth rate $\left(\%\right.$ day $\left.^{-1}\right), \mathrm{T}^{\circ}$ is the water temperature $\left({ }^{\circ} \mathrm{C}\right)$ and $\mathrm{M}$ is the fish mass $(\mathrm{g}), n$ is a coefficient taking into account the possibility that fish mass decrease (negative growth) when exposed to a particular extreme temperature, and $\mathrm{m}$ is $>1$. Since the amplitudes of the polynomial relationships between SGR and $\mathrm{T}^{\circ}$ are presumbly affected by fish mass $(\mathrm{M})$, a fourth interaction variable [i.e., $\left(\mathrm{T}^{\circ}\right.$ opt $) \cdot(\log (\mathrm{M}))$ or $\left.\log \left(\mathrm{T}_{\text {opt }}^{\circ}\right) \cdot(\log (\mathrm{M}))\right]$ should be added.

$$
\log (n+S G R)=a+b \cdot T \cdot[\text { or } \log (T)]+c \cdot T \cdot m \cdot[\operatorname{or} \log (T \cdot m)]+d \cdot \log (M)+e \cdot T^{P} \cdot \log (M) \cdot\left[\operatorname{or} \log \left(T^{P}\right) \cdot \log (M)\right]
$$

$P$ is a positive exponent and indicate the amplitude of the decrease of the optimal temperature for growth $\left(\mathrm{T}^{\circ}{ }_{\text {opt }}\right)$ in fish during their growth. In order to identify the target predictor variables and coefficients values (i.e., $\mathrm{T}^{\circ}$ or $\log \left(\mathrm{T}^{\circ}\right)$, the $\mathrm{m}$-values $=1$ or 2 ) gave the appropriate fit for the SGR developed model, a stepwise multiple-regression analysis was accomplished using the gathered data set (5-five-day periods $\times$ four experimental temperatures $\times$ four replications for each treatment).

Three important aspects should be considered in this model: i) the consistency of feed rations throughout the growth trial, ii) the periods over which growth is evaluated and iii) eventual size-depented fish mortality which can bias the estimation of the specific growth rates. These aspects were respected here, since fish were fed slightly in excess, and monitoring fish growth was regularly measured every 5 days. Therefore, mortality was extremely low throughout the period of this study. Two fish died and not considered in the analysis. 


\section{Results}

\subsection{Water Quality Monotoring}

No critical values were detected for dissolved oxygen $\left(>5.11 \mathrm{mg} \mathrm{L}^{-1}\right)$. Nitrite $\left(\mathrm{NO}_{2}-\mathrm{N}:<0.008 \mathrm{mg} \mathrm{L}^{-1}\right)$ and total ammonia- $\mathrm{N}\left(\mathrm{NH}_{3}-\mathrm{N}+\mathrm{NH}_{4}{ }^{+}-\mathrm{N}:<0.10 \mathrm{mg} / \mathrm{L}\right)$ remained within acceptable ranges for $O$. niloticus. The means of recorded water temperature are: $22 \pm 0.54,26 \pm 0.94,30 \pm 0.88$ and $34 \pm 1.04$ (mean $\pm \mathrm{SD})$.

\subsection{Growth Modeling}

The stepwise multiple-regression analysis approach generated a four-component model accounting for $93.9 \%$ of the variation of SGR (Table 1 and Figure 2) as follows:

$$
S G R\left(\% \mathrm{M} \mathrm{day}^{-1}\right)=-70.606+98.433 \cdot \log \left(T^{\circ}\right)-33.762\left[\log \left(T^{\circ}\right)\right]^{2}-0.153 \cdot \log (\mathrm{M}) \cdot\left[\log \left(T^{\circ}\right)\right]^{2}
$$

Table 1. Multiple regression model of growth $\left(\mathrm{SGR}, \%\right.$ day $\left.^{-1}\right)$ and fish mass $(\mathrm{M}, \mathrm{g})$ and rearing temperature $\left(\mathrm{T}^{\circ}\right)$ in juvenile Nile tilapia

\begin{tabular}{llll}
\hline Dependent variable: $\log (\mathrm{SGR})$ & \multicolumn{3}{c}{$\mathrm{F}=41.16$, d.f. $=15, \mathrm{P}<0.0001, \mathrm{r}^{2}=0.939$} \\
\cline { 2 - 4 } Predictor variables* & Coefficient & $\mathrm{SE}$ & $\mathrm{P}$ \\
\hline Intercept & -70.606 & 7.264 & $<0.0001$ \\
Log $\mathrm{T}^{\circ}$ & +98.433 & 10.127 & $<0.0001$ \\
$\left(\log \mathrm{T}^{\circ}\right)^{2}$ & -33.762 & 3.510 & $<0.0001$ \\
$\log \mathrm{M}\left(\log \mathrm{T}^{\circ}\right)^{2}$ & -0.153 & 0.058 & 0.0302 \\
\hline
\end{tabular}

Note. $*$ Predictor variables are presented in order of entrance in a stepwise multiple-regression analysis.

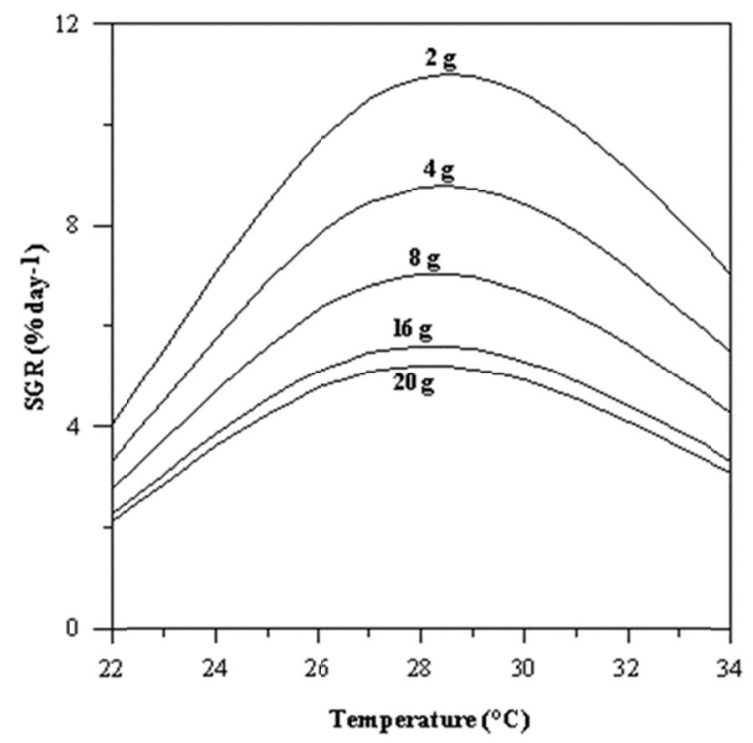

Figure 2. Abacus growth curves of juvenile Nile tilapia, depending on rearing temperature and body mass $(2,4,8$, 16 and $20 \mathrm{~g}$ ) from the developed model (Table 1)

\subsection{Gastric Evacuation Rate and Return of Appetite}

The rate of gastric emptying was considered to follow an exponential pattern and described by the equation:

$$
S_{t}=S_{0} \cdot e^{-R t}
$$

where, $\mathrm{S}_{\mathrm{t}}=$ stomach contents at time $\mathrm{t}$ (post-prandial); $\mathrm{S}_{0}=$ stomach contents at time 0 (after first feeding to satiation); $\mathrm{e}=$ natural logarithm; $\mathrm{R}=$ the instantaneous evacuation rate; $\mathrm{t}=$ time in hours $(\mathrm{h}$ ).

The above equation is expressed linearly in the following form:

$$
\log _{e}\left(S_{t}\right)=\log _{e}\left(S_{0}\right)-R t
$$


The relationships between stomach contents and time (gastric evacuation) for the four temperatures were illustrated in Table 2. As indicated in figure 3, the stomach evacuation rate was significantly affected by water temperature, this effect was examined by plotting evacuation rates $(\mathrm{R})$ against temperature (i.e., slope (R) $v s \log$ $\mathrm{T}^{\circ}, \mathrm{r}^{2}=0.981, \mathrm{~F}=102.6 ; \mathrm{df}=3 ; P=0.0144$ and 0.0096 for the slope and the intercept, respectively). The results showed that the evacuation rates increased with increasing temperature. The highest evacuation rate was seen in the $34^{\circ} \mathrm{C}$ groups, in which the proportion of meal remaining in the stomachs decreased from 100 to less than $2 \%$ after 18 hours of starvation.

Table 2. Regression equation of stomachs contents (\% BM) of juvenile Nile tilapia* after various deprivation periods $(2,4,6, \ldots 18$ hours) following a satiation meal (gastric evacuation) and reared at different water temperature $\left(\mathrm{T}^{\circ},{ }^{\circ} \mathrm{C}\right)$

\begin{tabular}{lllllll}
\hline $\mathrm{T}^{\circ}\left({ }^{\circ} \mathrm{C}\right)$ & Equation & $\mathrm{r}^{2}$ & $\mathrm{~F}$ & $\mathrm{df}$ & P intercept & P slope \\
\hline 22 & $\log \mathrm{S}_{\mathrm{t}}=1.099[0.034]-0.047[0.003] \mathrm{T}$ & 0.971 & 303.3 & 10 & $<0.0001$ & $<0.0001$ \\
26 & $\log \mathrm{S}_{\mathrm{t}}=1.065[0.039]-0.076[0.003] \mathrm{T}$ & 0.983 & 530.6 & 10 & $<0.0001$ & $<0.0001$ \\
30 & $\log \mathrm{S}_{\mathrm{t}}=1.014[0.032]-0.089[0.003] \mathrm{T}$ & 0.990 & 684.8 & 8 & $<0.0001$ & $<0.0001$ \\
34 & $\log \mathrm{S}_{\mathrm{t}}=1.038[0.029]-0.104[0.004] \mathrm{T}$ & 0.993 & 872.4 & 7 & $<0.0001$ & $<0.0001$ \\
\hline
\end{tabular}

Note. * Mean fish masses at the start of the gastric evacuation experiment were 6.94, 11.29, 14.02 and $8.73 \mathrm{~g}$ respectively for $22,26,30$ and $34{ }^{\circ} \mathrm{C}$ (These values correspond to the end of the growth trial).

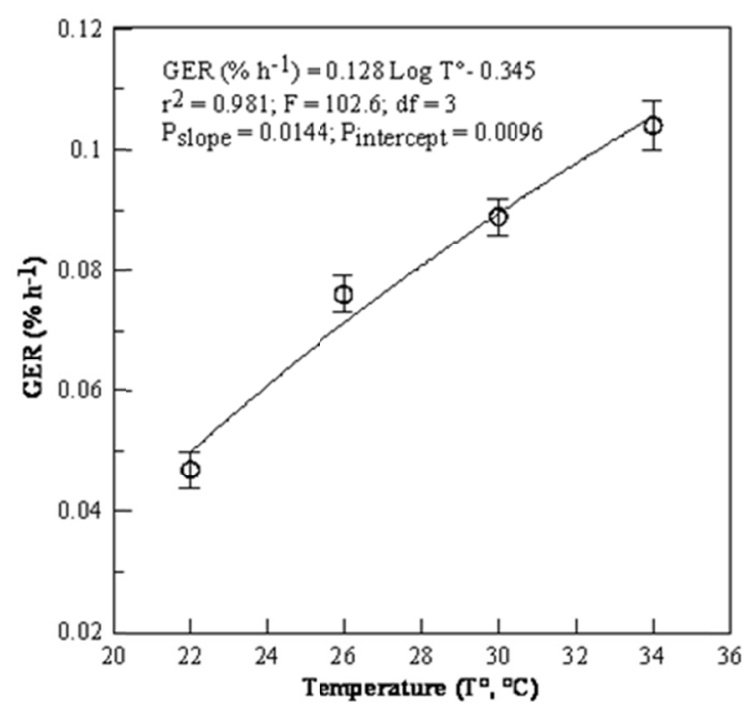

Figure 3. Effect of ambient water temperature upon gastric evacuation rate ( $\mathrm{R}$ in the gastric evacuation equations) in juvenile Nile tilapia reared at different water temperatures.

The ingested feed after different deprivation period (return of appetite, RA) in juvenile $O$. niloticus reared at 22, 26, 30 and $34{ }^{\circ} \mathrm{C}$ is shown in Table 3 . As indicated in Table 2, at 26,30 and $34^{\circ} \mathrm{C}$ the intercept is positive which means that the return of appetite markedly occurred before $\mathrm{t}=2$ hours, which is not the case at $22{ }^{\circ} \mathrm{C}$. Within the range $26-34{ }^{\circ} \mathrm{C}$, no significant difference $(P<0.001)$ in the slope of the regression of the return of appetite was detected (Table 3). From the Tables 2 and 3 (GER and RA, respectively), results show that in each rearing temperature, the sum of remaining feed after evacuation in relation to deprivation time and feed intake after the subsequent satiation meal close almost the stomach capacity (i.e., at each deprivation time fish consume as much as they have evacuated). 
Table 3. Regression equation of feed intake (\% BM) of juvenile Nile tilapia* after various deprivation periods following a satiation meal $(2,4,6, \ldots 18$ hours) (return of appetite) and reared at different water temperature $\left(\mathrm{T}^{\circ},{ }^{\circ} \mathrm{C}\right)$.

\begin{tabular}{lllllll}
\hline $\mathrm{T}^{\circ}\left({ }^{\circ} \mathrm{C}\right)$ & Equation & $\mathrm{r}^{2}$ & $\mathrm{~F}$ & $\mathrm{df}$ & $\mathrm{P}$ intercept & P slope \\
\hline 22 & $\log \mathrm{S}_{\mathrm{t}}=-0.091[0.022]+0.729[0.022] \log \mathrm{T}$ & 0.992 & 1134 & 10 & 0.0029 & $<0.0001$ \\
26 & $\log \mathrm{S}_{\mathrm{t}}=0.303[0.045]+0.547[0.045] \log \mathrm{T}$ & 0.948 & 146.7 & 9 & 0.0002 & $<0.0001$ \\
30 & $\log \mathrm{S}_{\mathrm{t}}=0.302[0.019]+0.540[0.020] \log \mathrm{T}$ & 0.991 & 760.5 & 8 & $<0.0001$ & $<0.0001$ \\
34 & $\log \mathrm{S}_{\mathrm{t}}=0.300[0.016]-0.566[0.016] \log \mathrm{T}$ & 0.994 & 1293 & 9 & $<0.0001$ & $<0.0001$ \\
\hline
\end{tabular}

Note. ${ }^{*}$ Mean fish masses were $6.94,11.29,14.02$ and $8.73 \mathrm{~g}$ respectively for $22,26,30$ and $34{ }^{\circ} \mathrm{C}$. (These values correspond to the end of the growth trial).

Since the rate of return of appetite is inversely proportional to gastric evacuation, maximum consumption at any time after satiation can thus be estimated as: Consumption at time $\mathrm{t}\left(\mathrm{C}_{\mathrm{t}}\right)$ can be determined as follows:

$$
C_{t}=S_{0}-S_{t}=S_{0}-S_{0} \cdot e^{-R t}=S_{0}-\left(1-e^{-R t}\right)
$$

Estimated maximum daily consumption (e.g., daylight feeding; $12 \mathrm{~h}$ ) can be expressed by:

$$
C_{12 \mathrm{~h}}=(12 / t) \cdot C_{t}
$$

Where, " $t$ " is the feeding interval in hours or $12 / t$ is the feeding frequency. The estimated maximum daily feed intake $\left(\% \mathrm{M} \mathrm{day}^{-1}\right)$ is represented in Figure 4. This figure clearly shows that a larger amount of feed intake accelerates the stomach evacuation rate. Also, results demonstrate that maximum daily feed intake is correlated to feeding frequency. This correlation is strongly marked at 26,30 and $34{ }^{\circ} \mathrm{C}$ treatments, compared to $22{ }^{\circ} \mathrm{C}$.

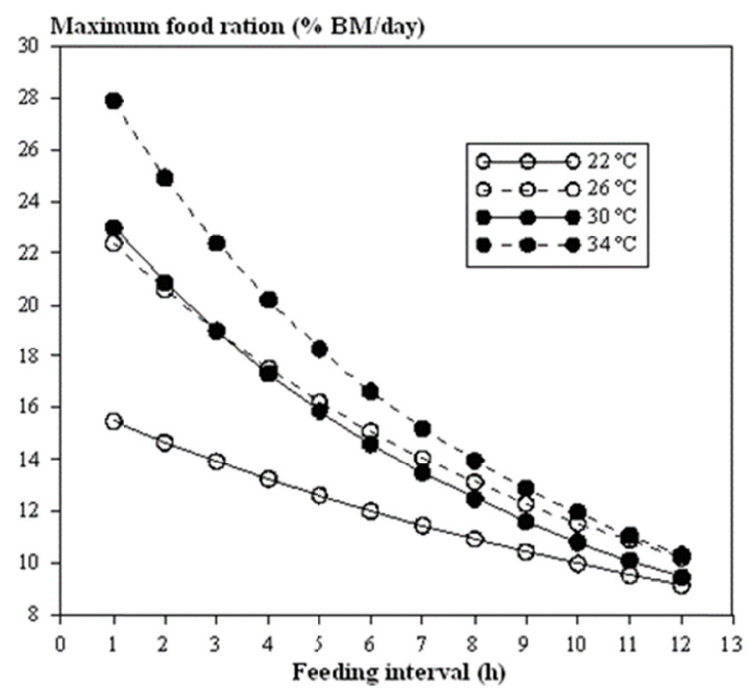

Figure 4. Estimated maximum feed intake (\% body mass day $\left.{ }^{-1}\right)$ for juvenile Nile tilapia (mass: 6-14 g) reared at different temperature $\left(22,26,30\right.$ and $\left.34^{\circ} \mathrm{C}\right)$ and feeding schedule over $12 \mathrm{~h}$

\section{Discussion}

A high statistical aptness growth model was developed using a stepwise multiple-regression analysis across fish mass and water temperature $\left(r^{2}=0.939, \mathrm{df}=15\right)$. However, it seemely that this model cannot be extrapolated to any set of environmental rearing conditions. Baras et al. (2002) reported that the optimal temperature $\left(\mathrm{T}^{\circ}{ }_{\text {opt }}\right)$ decreases with decreasing oxygen levels, since an increase in metabolism with increasing temperature can only be maintained under high dissolved oxygen availability. Tran-Duy et al. (2008) demonstrated that feed consumption and growth of $O$. niloticus of average mass of 37 and $190 \mathrm{~g}$, remarkably decreased when dissolved oxygen concentrations of about 2.8 and $3.2 \mathrm{mg} \mathrm{L}^{-1}$, respectively. Similarly, according to Tsadik and Kutty (1987), feed intake of $O$. niloticus of $8.1 \mathrm{~g}$ decreased $40 \%$ when ambient dissolved oxygen decreases from 7.0 to $1.5 \mathrm{mg}$ $\mathrm{L}^{-1}$. In the present study, the effect of oxygen concentration was low since the lowest recorded DO level was above $5.11 \mathrm{mg} \mathrm{L}^{-1}$, and it is unlikely that the optimal temperature $\left(\mathrm{T}^{\circ}{ }_{\mathrm{opt}}\right)$ be highly underestimated. It may be 
argued whether feed quality effect or whether changing the energy content and protein levels influenced the results. The influence of feed quality was probably minimal since in the diet used in this study, dietary protein and energy content were enough to support maximum growth for $O$. niloticus in the range size tested in this study.

A multitude of models have been developed to describe gastric emptying in fish (Bromley, 1994). The developed regression analysis of the gastric evacuation time in the present study follows an exponential regression function. Previous studies corroborhate that the exponential model is the most appropriate to describe the evacuation of small digestible feed particles (Jobling, 1987). This relationship has also been demonstrated in $O$. niloticus (Riche et al., 2004; Azaza et al., 2010b), Oreochromis mossambicus (De Silva \& Owoyemi, 1983). Enzyme activity follows an exponential function and is obviously affected by temperature. Therefore, it is possible that the exponential regression may be more adequate for $O$. niloticus fed on particle feed and reared in warmer temperatures (Brodeur, 1984).

GERs (about $0.089 \% \mathrm{~h}^{-1}$ ) and GETs (approximately 20-22 $\mathrm{h}$ ) for $14 \mathrm{~g}$-fish reared at $30{ }^{\circ} \mathrm{C}$ are slower than this reported by Riche et al. (2004) which show that $O$. niloticus $(183 \mathrm{~g})$ take circa $18 \mathrm{~h}$ to empty their stomach at $28{ }^{\circ} \mathrm{C}$. Some of the difficulty in comparing studies can be attributed to the different experimental conditions or analytical procedures involved. Jobling et al. (2012) reviewed some of the factors that are thought to influence these rates. It concludes that feed type may often affect the evacuation rate through the efficiency of its digestibility. On the other hand, feed particle size is an important factor that affects emptying in catfish (Hossain et al., 2000) and O. niloticus (Azaza et al., 2010b). As observed in other fish species such as Pikeperch (Koed, 2001) and Atlantic salmon (Handeland et al., 2008), the evacuation rate of juvenile $O$. niloticus was strongly temperature-dependent. The influence of temperature on gastric evacuation was examined by plotting the instantaneous evacuation rates $(\mathrm{Re})$ against the experimental temperatures and the results showed that evacuation rates increased with increasing temperature and varied significantly among test temperatures $\left(\mathrm{F}_{3,63}=5.68, P<\right.$ 0.001). The Re increased from 0.047 to $0.104 \% \mathrm{~h}^{-1}$ between 22 and $34{ }^{\circ} \mathrm{C}$. A Van't Hoff's $Q_{10}$ value of Re over the temperature range of $22-34{ }^{\circ} \mathrm{C}$ was 0.0475 , which indicates that the metabolic rate of $O$. niloticus $(6-14 \mathrm{~g})$ nearly double for a $10{ }^{\circ} \mathrm{C}$ increase of temperature. Pääkkönen and Marjomäki (1997) calculate a $Q_{10}$ value of 2.89 for burbot Lota lota, which is circa six-fold of the value obtained here for juvenile O. niloticus. This indicates that the burbot is more sensitive to water temperature than $O$. niloticus and confirms the eurythermic specificity of this latter species. This parameter seems to be depending on fish species due to the difference in metabolic process and growth caracteristics (Brett \& Groves, 1979). The relationship of Re vs rearing temperature follow a logarithmic pattern $\left(\mathrm{GER}=0.128 \cdot \log \left(\mathrm{T}^{\circ}\right)-0.345 ; \mathrm{R}^{2}=0.981, n=5\right)$. Based on this relationship (equation), the the temperature for $O$. niloticus at which Re is zero (the regression line passes through zero) was estimated, thus theoretically fish feeding is stopped. This analysis suggests that the temperature threshold of ceased voluntary feed intake is $18.5^{\circ} \mathrm{C}$ for $O$. niloticus of masses between 6 and $14 \mathrm{~g}$.

In salmonids, previous studies show that GER increases exponentially as temperature increases (e.g., Sweka et al., 2004), and that GER depends primarily on rearing temperature and feed intake act as a secondary factor (e.g., Kawaguchi et al., 2007; Azaza et al., 2010b). It has been shown that water temperature may affect feed utilization efficiency and growth performance by affecting the gastrointestinal transit time (Dos Santos \& Jobling, 1995). Fish submitted to higher water temperature $\left(34{ }^{\circ} \mathrm{C}\right.$ in the present study) evacuated more quickly, resulting from a temperature dependent increase in gastric peristalsis. In this situation, feed is attending the intestine without engouh gastric digestion thus decreasing significantly the enough time for digestion, possibly negatively affecting nutrient absorption efficiency (Jobling et al., 2012).

In aquaculture, much attention should be accorded to the return of appetite after a satiation meal (Hossain et al., 1998; Riche et al., 2004). During a meal, an animal achieved satiaty, when internal physiological signals act as negative feedback, which at a certain threshold will instruct the animal to cease eating (Langhans, 1999). In the time after this satiation meal (deprivation time) when the ingested feed is processed (digested and assimilated), the animal becomes hungry again (return of appetite). At this moment, fish re-fed to full the new empty space in their stomach (Jobling et al., 2012). Results of the present study show that the return of appetite in juvenile $O$. niloticus after a single satiation meal closely follows the gastric evacuation curve and when fish were offered feed, the fish adjust their intake, so that stomach fulness is maintained at near maximum fulness, i.e., gastric evacuation and return of appetite were inversely shaped. This relationship between GER and feed intake (i.e., return of appetite) has been demonstrated in O. niloticus (Riche et al., 2004; Azaza et al., 2010b) and is common to other fish species (Hossain et al., 1998).

The slope of the regression of the GER increased with increasing temperature. It is worth to note, as indicated above, that evacuated feed was immediately replaced when fish were offered feed, to adjust their intake, so that 
stomach fulness is maintained. This implies that the two physiological processes (i.e., evacuation and return of appetite) occur at a comparable rate only in a range of temperatures around the optimal temperature of the species $\left(28-32{ }^{\circ} \mathrm{C}\right)$. Lee et al. (2000) demonstrated that feeding intervals or feeding frequency is significantly correlated with gastric evacuation time, and the return of appetite is closely related to the rate of gastric emptying. In fish culture, making feed available at an appropriate rate and as soon as appetite has returned, can maximize feed intake and not obviously improve utilization feed efficiency. Besides, a suitable feeding strategy is essential not only in terms of improvement of fish growth but also in terms of reduction of feed cost and environmental problems. In practice, appetite combined with the daily number of meals, often named "the applied feeding frequency" or feeding schedule will allow an optimal feeding strategy to be predicted under a given set of rearing conditions and diets specificities. In this study, two parameters were used to develop appropriate feeding strategies in relation to water temperature and feeding frequency. Observations on the maximum daily feed intake in $O$. niloticus suggest a strong temperature dependent regulation of feed intake through the return of appetite. In fact, there was doubling of maximum feed intake of fish reared at $34{ }^{\circ} \mathrm{C}$ compared to those reared at $22^{\circ} \mathrm{C}$. For example, this analysis shows that, for a temperature of $30^{\circ} \mathrm{C}$, fish (circa $10 \mathrm{~g}$ ) fed every hour for 12 hours consume $23 \%$ of their body mass; however, they consume only $14.6 \%$ of their mass if the meals were distributed every 6 hours. In the absence of parallel growth data, it is not possible to specify whether the growth is proportional to the feed ration, which is plausible, but probably not with a slope of 1.00 , because it is evident that when GER increases, digestibility and feed conversion efficiency decrease. From a practical point of view, it is important to assess if the observed variations in maximum feed intake related to feeding frequency influence the feed conversion efficiency.

\section{Conclusion}

The results of the present study allow aquaculturists to select and adapt the suitable feed management based on the rearing temperature. This allows avoiding either under-feeding, which inhibits growth and enhances growth dispersion (Azaza et al., 2013), or over-feeding, which increases feed wastage and reduces feed conversion efficiency.

\section{References}

APHA (American Public Health Association). (1995). Standard Methods for the Examination of Water and Waste Water (19th ed.). American Public Health Association, Washington, DC, USA.

Azaza, M. S, Wassim, K., Mensi, F., Abdelmouleh, A., Brini, B., \& Kraïem, M. M. (2009). Evaluation of faba beans Vicia faba L. (var. minuta) as a replacement for soybean meal in practical diets of juvenile Nile tilapia Oreochromis niloticus L., 1758. Aquaculture, 287, 174-179. https://doi.org/10.1016/j.aquaculture.2008. 10.007

Azaza, M. S., Assad, A., Maghrbi, W., \& El-Cafsi, M. (2013). The effects of rearing density on growth, size heterogeneity and inter-individual variation of feed intake in monosex male Nile tilapia Oreochromis niloticus L. Animal, 7, 1865-1874. https://doi.org/10.1017/S1751731113001493

Azaza, M. S., Dhraïef, M. N., \& Kraïem, M. M. (2008). Effects of water temperature on growth and sex ratio of juvenile Nile Tilapia Oreochromis niloticus (Linnaeus) reared in geothermal waters in southern Tunisia. Journal of Thermal Biology, 33, 98-105. https://doi.org/10.1016/j.jtherbio.2007.05.007

Azaza, M. S., Dhraïef, M. N., Kraïem, M. M., \& Baras, E. (2010b). Influences of food particle size on growth, size heterogeneity, feed efficiency and gastric evacuation of juvenile Nile tilapia, Oreochromis niloticus (Linnaeus, 1758). Aquaculture, 309, 193-202. https://doi.org/10.1016/j.aquaculture.2010.09.026

Azaza, M. S., Khiari, N., Dhraief, M. N., Kraïem, M. M., \& Elfeki, A. (2015). Growth performance, oxidative stress indices and hepatic carbohydrate metabolic enzymes activities of juvenile Oreochromis niloticus (L.), in response to dietary carbohydrate to protein ratio. Aquaculture Research, 46, 14-27. https://doi.org/ $10.1111 /$ are. 12153

Azaza, M. S., Legendre, M., Kraïem, M. M., \& Baras, E. (2010a). Size-dependent effects of fluctuating thermal regimes on the growth and size heterogeneity of Nile tilapia. Journal of Fish Biology, 76, 669-683. https://doi.org/10.1111/j.1095-8649.2009.02524.x

Baras, E., Mpo'N'Tcha, A., Driouch, H., Prignon, C., \& Mélard, Ch. (2002). Ontogenetic variations of thermal optimum for growth, and its implication on thermolabile sex determination in blue Tilapia. Journal of Fish Biology, 61, 645-660. https://doi.org/10.1111/j.1095-8649.2002.tb00902.x 
Baras, E., Prignon, C., Gohoungo, G., \& Mélard, C. (2000). Phenotypic sex differentiation of blue Tilapia under constant and fluctuating thermal regimes and its adaptive and evolutionary implications. Journal of Fish Biology, 57, 210-223. https://doi.org/10.1111/j.1095-8649.2000.tb00787.x

Brett, J. R., \& Groves, T. D. D. (1979). Physiological energetics. In W. S. Hoar, D. J. Randall \& J. R. Brett (Eds.), Fish Physiology (Vol. VIII, pp. 279-352). London: Academic Press. https://doi.org/10.1016/S1546-5098 (08)60029-1

Brodeur, R. D. (1984). Gastric evacuation rates for two foods in the black rockfish, Sebastes melanops Girard. Journal of Fish Biology, 24, 287-298. https://doi.org/10.1111/j.1095-8649.1984.tb04800.x

Bromley, P. J. (1994). The role of gastric evacuation experiments in quantifying the feeding rates of predatory fish. Reviews in Fish Biology and Fisheries, 4, 36-66. https://doi.org/10.1007/BF00043260

De Silva, S. S., \& Owoyemi, A. A. (1983). Effect of dietary quality on the gastric evacuation and intestinal passage in Sarotherodon mossambicus (Peters) fry. Journal of Fish Biology, 23, 347-355. https://doi.org/ 10.1111/j.1095-8649.1983.tb02914.x

Dos Santos, J., \& Jobling, M. (1995). Test of a food consumption model for the Atlantic cod. ICES, Journal of Marine Science, 52, 209-219. https://doi.org/10.1016/1054-3139(95)80036-0

El-Asely, A. M., Ayman, R. M. R., Mohamed, S., Mahmoud, A. M., Dawood, A. O. (in press). Overall performances of Nile tilapia (Oreochromis niloticus) associated with using vegetable oil sources under suboptimal temperature. Aquaculture Nutrition. https://doi.org/10.1111/anu.13072

Food and Agriculture Organization of the United Nations. (2019). FAO's fisheries and aquaculture department. Statistical collections capture production and aquaculture production datasets 1950-2019. Retrieved from http://www.fao.org/fishery/topic/16073

Handeland, S. O., Imsland, A. K., \& Stefansson, S. O. (2008). The effect of temperature and fish size on growth, feed intake, food conversion efficiency and stomach evacuation rate of Atlantic salmon post-smolts. Aquaculture, 283, 36-42. https://doi.org/10.1016/j.aquaculture.2008.06.042

Hossain, M. A. R., Haylor, G. S., \& Beveridge, M. C. M. (1998). Quantitative estimation of maximum daily feed intake of African catfish, Clarias gariepinus Burchell, fingerlings using radiography. Aquaculture Nutrition, 4, 175-182. https://doi.org/10.1046/j.1365-2095.1998.00063.x

Hossain, M. A. R., Haylor, G. S., \& Beveridge, M. C. M. (2000). The influence of food particle size on gastric emptying and growth rates of fingerling African catfish, Clarias gariepinus Burchell, 1822. Aquaculture Nutrition, 6, 73-76. https://doi.org/10.1046/j.1365-2095.2000.00131.x

Houlihan, D., Boujard, T., \& Jobling, M. (2001). Food Intake in Fish (p. 418). Blackwell Science Ltd., Oxford. https://doi/abs/10.1002/9780470999516

Jobling, M. (1987). Influences of food particle size and dietary energy content on patterns of gastric evacuation in fish: Test of a physiological model of gastric emptying. Journal of Fish Biology, 30, $299-314$. https://doi.org/10.1111/j.1095-8649.1987.tb05754.x

Jobling, M., Alanärä, A., Noble, C., Sánchez-Vázquez, J., Kadri, S., \& Huntingford, F. (2012). Appetite and feed intake. In F. Huntingford, M. Jobling, \& S. Kadri (Eds.), Aquaculture and Behaviour (pp. 183-219). Wiley-Blackwell, West Sussex, UK. https://doi.org/10.1002/9781444354614

Kawaguchi, Y., Miyasaka, H., \& Genkai-Kato, M. (2007). Seasonal change in the gastric evacuation rate of rainbow trout feeding on natural prey. Journal of Fish Biology, 71, 1873-1878. https://doi.org/10.1111/ j.1095-8649.2007.01647.x

Koed, A. (2001). The effects of meal size, body size and temperature on gastric evacuation in Pike perch. Journal of Fish Biology, 58, 281- 290. https://doi.org/10.1111/j.1095-8649.2001.tb00514.x

Langhans, W. (1999). Appetite regulation. In G. E. Lobley, A. White, \& J. C. MacRae (Eds.), Protein metabolism and nutrition (pp. 225-251). Wageningen Pers, Wageningen, The Netherlands.

Lee, S. M., Hwang, U. G., \& Cho, S. H. (2000). Effects of feeding frequency and dietary moisture content on growth, body composition and gastric evacuation of juvenile Korean rockfish (Sebastes schlegeli). Aquaculture, 187, 399-409. https://doi.org/10.1016/S0044-8486(00)00318-5

Pääkkönen, J.-P., \& Marjomäki, T. J. (1997). Gastric evacuation rate of burbot fed single-fish meals at different temperatures. Journal of Fish Biology, 50, 555-563. https://doi.org/10.1111/j.1095-8649.1997.tb01949.x 
Riche, M., Haley, D. I., Oetker, M., Garbrecht, S., \& Garling, D. L. (2004). Effect of feeding frequency on gastric evacuation and the return of appetite in Tilapia Oreochromis niloticus (L.). Aquaculture, 234, 657-673. https://doi.org/10.1016/j.aquaculture.2003.12.012

Sweka, J. A., Cox, M. K., \& Hartman, K. J. (2004). Gastric evacuation rates of brook trout. Transaction American Fish Society, 133, 204-210. https://doi.org/10.1577/T02-064

Temming, A., \& Andersen, N. G. (1994). Modelling gastric evacuation without meal size as a variable. A model applicable for the estimation of daily ration of cod (Gadus morhua L.) in the field. ICES Journal of Marine Science, 51, 429-438. https://doi.org/10.1006/jmsc.1994.1044

Tran-Duy, A., Schrama, J. W., Van Dam, A. A., \& Verreth, J. A. (2008). Effects of oxygen concentration and body weight on maximum feed intake, growth and hematological parameters of Nile Tilapia, Oreochromis niloticus. Aquaculture, 275, 152-162. https://doi.org/10.1016/j.aquaculture.2007.12.024

Tsadik, G. G., \& Kutty, M. N. (1987). Influence of ambient oxygen on feeding and growth of the Tilapia, Oreochromis niloticus (Linnaeus) (Working paper ARAC/87/WP/10, p. 13). African Regional Aquaculture Centre, Port Harcourt, Nigeria.

\section{Copyrights}

Copyright for this article is retained by the author(s), with first publication rights granted to the journal.

This is an open-access article distributed under the terms and conditions of the Creative Commons Attribution license (http://creativecommons.org/licenses/by/4.0/). 